\title{
Radical Capitalism as a Coherentist Philosophy
}

\author{
By Andreas Lind ${ }^{*}$
}

\begin{abstract}
Analyzing the connection between nominalism and capitalism, Radical Orthodoxy's authors see Nietzsche as the one who gave the operative principle to the liberal nominalist tradition: the will-topower. In their point of view, capitalism is based on the principle that each individual who operates in the free market, attempts to impose by power his own will against others. Thus, nominalism affirms that different individuals have contradictory wills. Based on the subprime crisis in 2007, one could argue that the nominalist philosophy played a role in contemporary capitalism, not only in the matter of individual will, but also by being focused on the logical coherence of the system, rather than focusing on any kind of realistic foundation. By rejecting ontology, nominalism made validity, that is, logical coherence, the main criterion for accepting a system. The massive practice of subprime credits, which brought about a global financial crisis, was only possible within this nominalist perspective of validity. This perspective allowed the granting of credit based only on the speculative increase of house prices, the practice at the origin of the present global financial crisis.
\end{abstract}

\section{Introduction}

Since the subprime crisis of 2007, there has been much literature across many fields criticizing "neo-liberalism" (i.e. the radically deregulated free market economy as first proposed in the 1970s). For many, the 2007 crisis vindicated critics of the FED's and IMF's policy of deregulation in the 1980s and 1990s. According to these critics, such as Nobel Prize winner Joseph Stiglitz, ${ }^{1}$ the policy of deregulation was too narrowly focused on inflation. Even the ex-President of the FED from that time, Alan Greenspan, admitted that something had not worked. ${ }^{2}$

Some authors go even further, saying that the 2007 crisis was not simply a failure of radical capitalism, but the beginning of the fall of the free market paradigm. They cite Thomas Kuhn, applying his thesis in the economic-political field, in order to show how contemporary economics insist on applying solutions from the neo-liberal paradigm which have consistently failed to achieve the promised results. ${ }^{3}$

\footnotetext{
*Independent Scholar, Portugal.

1. Joseph Stiglitz, Globalization and its discontents (New York: W.W. Norton \& Company, 2002), 34, 86-87.

2. "(...) it turned out that I'd been wrong to abandon my skepticism about the ongoing surplus. Those rosy ten-year forecasts were in fact utterly mistaken." (Alan Greenspan, The age of turbulence: adventures in a new world (New York: Pinguin Press, 2007), 224).

3. Hugo Assmann, \& Franz J. Hinkelammert, L'idolâtrie de marché: critique théologique de l'économie de marché (Idolatry market: theological critique of the market
} 
One thing, at least, is clear: we are living through a real crisis of the free market system. In fact, even Francis Fukuyama, who predicted the triumph of liberal democracies all over the world, ${ }^{4}$ now maintains (in light of the 2007 crisis) that Western society is itself in danger and may fail in the future. ${ }^{5}$

In the context of the profound global crisis, it is natural that those who criticized previous economic policies find in such a crisis proof for their positions. Critiques of free market economy (or "neo-liberalism," as it is called by its critics) have been developed not only in the fields of economics and politics, but in sociology, and even philosophy and theology.

The critique made in these latter fields relies on a form of Liberation Theology. But unlike traditional Liberation Theology, which was aimed at the particular context of Latin America, this new variant is global in that it attacks the foundational principles of economics. ${ }^{6}$ This hybrid of theology, philosophy, and economics can be seen especially in the relatively new theological and philosophical movement called Radical Orthodoxy. ${ }^{7}$

economy), trans. C. Durban, \& L. Durban (Paris: Cerf, 1993), 30-31. "Le grand défi actuel, c'est un changement de paradigme (The great challenge now is a paradigm shift)" (Gaël Giroud, \& Cécile Renouard, Vingt propositions pour réformer le capitalisme (Twenty proposals to reform capitalism) (Paris: Flamarion, 2012), 26). "Un changement de paradigme s'impose (A paradigm shift is needed)" (Giroud and Renouard, Vingt propositions pour réformer le capitalisme, 320).

4. "I argued that a remarkable consensus concerning the legitimacy of liberal democracy as a system of government had emerged throughout the world over the past few years, as it conquered rival ideologies like hereditary monarchy, fascism, and most recently communism. More than that, however, I argued that liberal democracy may constitute the 'end point of mankind's ideological evolution' and the 'final form of human government,' and as such constituted the 'end of history."' (Francis Fukuyama, The end of History and the last man (New York: Free Press, 1992), xi).

5. "(...) there is no guarantee that this self-correction will occur, perhaps because the nonelites are poorly organized, or they fail to understand their own interests correctly." (Francis Fukuyama, Political order and political decay: from the industrial revolution to the globalization of democracy (New York: Farrar Straus and Giroux, 2014), 27).

6. Geraldo de Mori, "Une théologie à l'école des pauvres: les nouvelles 'frontières' de la théologie de la libération (A theology at the school of the poor: the new 'boundaries' of liberation theology)," Revue théologique de Louvain, 46, no. JuilletSeptembre (2015): 372-373.

7. "Our current global situation is different, and yet is in essential continuity with the circumstances in which this book was written. Today, neo-liberalism has further extended its sway, but has now begun to mutate into a new mode of political tyranny." (John Milbank, Theology and social theory: beyond secular reason (Oxford: Blackwell, 2006), xi). Milbank is, indeed, quite violent in his critiques against modern liberal tradition: "European and American liberal democracy has also engendered a continuous horror almost as grave as the Holocaust, and a more troublingly sustainable mode of nihilism, appropriately disguised by an unparalleled reign of 
Yet this is not the only variety of theological critique being made about neo-liberalism. Even the Magisterium of the Catholic Church has been assuming a critical position towards free market economy, as we see in Benedict XVI's encyclical Caritas in veritate, and in Pope Francis' recent apostolic exhortation Evangelii gaudium and his most recent encyclical Laudato Si'. The two popes asked for international institutions such as the United Nations to promote a structural reform of economics at an international level. ${ }^{8}$

According to this theological-philosophical critique, neo-liberalism implies a problematic theology. ${ }^{9}$ For, a radical free market inevitably promotes the ideals of force, efficiency, autonomy of choice - the "credo of the market" (using Assmann's terminology $)^{10}$ - as the criteria by which we understand reality. And how we understand reality affects how we perceive God.

Thinkers from the movements of both Radical Orthodoxy and Liberation Theology assert that neo-liberalism is in one way too realistic. According to neo-liberalism, things like austerity and unemployment are inevitable. ${ }^{11}$ And

kitsch (including the American Holocaust industry): this is the sequence of deliberate terror and extermination deployed against civilian populations as a primary instrument of war and neo-colonial power from the Congo and the Philippines through Hiroshima, Palestine, Kenya, Algeria and Vietnam to the Gulf War and Afghanistan. This sequential instance - unparalleled in pre-modernity - shows that the source of terror is not simply "totalitarianism," but rather the emptiness of secular power as such. It also shows that "liberal democracy" is a mere virtual circus designed to entertain the middle-classes of the privileged world." (John Milbank, Being reconciled: ontology and pardon (London: Routledge, 2003), 5).

8. "In the face of the unrelenting growth of global interdependence, there is a strongly felt need, even in the midst of a global recession, for a reform of the United Nations Organization, and likewise of economic institutions and international finance, so that the concept of the family of nations can acquire real teeth." (Pope Benedict XVI, "Encyclical Letter Caritas in veritate [26 Jun. 2009]," AAS 101 (2009), 641-709 §67). "In this context, some people continue to defend trickle-down theories which assume that economic growth, encouraged by a free market, will inevitably succeed in bringing about greater justice and inclusiveness in the world. This opinion, which has never been confirmed by the facts, expresses a crude and naive trust in the goodness of those wielding economic power and in the sacralized workings of the prevailing economic system." (Pope Francis, "Apostolic Exhortation Evangelii gaudium [24 Nov. 2013]," 256: AAS 105 (2013), 1123 §54).

9. Some go so far as to call it a "perverse theology" (Assmann and Hinkelammert, L'idolâtrie de marché: critique théologique, 22-23).

10. Assmann and Hinkelammert, L'idolâtrie de marché: critique théologique, 33-138.

11. Assmann and Hinkelammert, L'idolâtrie de marché: critique théologique, 186-187. "In the case of libertarians, one is confronted with the phenomenon of a Whiggism undismayed by any evidence. The most astonishing thing about this tendency (as represented by Anthony Giddens and others) is that it remains more attached to the most metaphysical element of the Marxist legacy, namely its fatalist and logicist belief in capitalism as "a necessary stage" in human history, than to its more rigorous and 
proponents of Radical Orthodoxy and Liberation Theology argue that economic systems ought to be "utopian," and not merely accept reality as it comes.

However, the philosophical and theological problem of neo-liberalism is rather a lack of realism. I agree with John Milbank that liberalism (in the traditional sense) is connected to nominalism..$^{12}$ But, for me, this connection implies also the abandonment of a foundationalist philosophy in favor of a coherentist one.

In the present article I propose to show how, based on the subprime crisis in 2007, nominalist philosophy influenced contemporary capitalism. This influence can be seen in contemporary capitalism's emphasis on individual choice (i.e. will) [as Milbanks notes], as well as in how it focuses on the logical coherence of its principles (coherentism) while neglecting to consider whether its principles have a foundation in reality (foundationalism). By rejecting ontology, nominalism made validity-that is, logical coherence-the main criterion for accepting a system. It was precisely this neglect of realistic thinking and this exaggerated emphasis on validity that led to the widespread practice of irresponsibly granting credit based on tenuous and speculative predictions regarding the value of houses - the issue that sparked the present global financial crisis.

\section{Radical Capitalism Is Based on Nominalism}

\section{There Is No Neutrality}

Neo-liberal contemporary policy, in the main European and international institutions such as the IMF and $\mathrm{ECB},{ }^{13}$ presumes that "market forces" are something that belongs to nature itself. This means that neo-liberal economics is not only the "best option that we have," but is also ideologically neutral. Neo-liberal authors such as Hayek explicitly take this for granted. ${ }^{14}$

In fact, the principles of the free market establish a rationality that would be, for contemporary neo-liberal economists, strictly scientific: namely,

scientific aspect, namely its deconstruction of the logic of capitalist organization. Hence it implies that global neo-liberalization since the 1970s must be understood as a necessary and continuing sweeping away of paternalist, almost quasi-feudal relics: the new world-wide "revolt against deference" shows that socialists were wrong to assume that the road of the liberal via negativa had been travelled to the end." (Milbank, Being reconciled: ontology and pardon, 163).

12. "It is in this inescapable imperative of nominalism-voluntarism that one discovers the kinship at root of modern absolutism with modern liberalism." (Milbank, Theology and social theory:, 14).

13. IMF - International Monetary Fund; ECB - European Central Bank.

14. Assmann and Hinkelammert, L'idolâtrie de marché: critique théologique, 122-123. 
reason. However, such principles do not belong to the nature of human society; moreover, they have hidden presuppositions that are not neutral.

Hugo Assmann and Franz Hinkelammert say as much in their critique against contemporary neo-liberalism. They show that the principles of the free market assume, even if only implicitly, a specific anthropology which cannot be deduced purely by reason. ${ }^{15}$ Namely, free market economics assume that people are rational and are able to identify their best options (economically measured) and choose them. ${ }^{16,17}$ Theologically speaking, we could say that this anthropology fails to account for original sin and its effects (fallen human nature).

Hence, as John Milbank shows, "neutral rationality," the dream of modernity, is a mythos. That is what we have learned from Nietzsche: there is no such thing as neutral rationality-all appeals to rationality are based on contingent presuppositions about human nature, which can only be applied in a particular context. We cannot access nature itself: we can only propose a narrative that is historical and particular-not absolute. ${ }^{18}$ Neo-liberal economics, then, is only one possible narrative according to which human beings can organize their lives. So, capitalism is one way of living among many; it is not the way that is established necessarily by nature.

In this sense, Radical Orthodoxy's authors, such as Milbank, Graham Ward, and Stephen Long, think that we are entering a new cultural phase called The Post-Secular. As with leading post-modern authors, they try to make their arguments using narration; namely, they accept that reason cannot explain facts, but only interpret them. Since they are aware of the impossibility of building knowledge based on an absolute, neutral and universal reason, as people attempted to do in the past, these authors show that each interpretation has its own presuppositions, which are grounded in theology (as we will discuss below) ${ }^{19}$

Thus, secular neutrality is something that does not exist, because each interpretation/narration contains, implicitly, a philosophy and theology behind itself. So the main question becomes: "Which kind of theology and philosophy is implicit in economic theories?"20

15. Ibid., 81-85.

16. Milbank, Theology and social theory:, 14-15.

17. This is the idea of the father of liberalism, Adam Smith, of an "invisible hand" that automatically puts the market in equilibrium (Assmann and Hinkelammert, L'idolâtrie de marché: critique théologique, 108).

18. Milbank, Theology and social theory:, 269-270.

19. Milbank, Theology and social theory:, 281-282.

20. Assmann and Hinkelammert, L'idolâtrie de marché: critique théologique, 82. 


\section{Nominalism in the Establishment of Capitalism}

Milbank detects, inside neo-liberal economic principles, the theological idea of nominalism, according to which the world (nature) is completely independent from God's logos. ${ }^{21}$ We must notice that this is the nucleus of nominalism. It means that when we, following Radical Orthodoxy's authors, affirm that capitalism contains and implies (implicitly) a nominalist philosophy, we are not saying that captalism and its adherents presume that the World was made by God's Will: they only presume that reality is independent from God's logos or from the logos of a given exterior reality.

Nominalism was born in the late medieval age by Scotus and Ockham, who opposed the thomistic idea of participation.22 Their main concern was a theological one. The first nominalists wanted to defend God's omnipotence. In order to do that, they made a radical separation between God and the world; between nature, which is creature, and its Creator: in other words, between reality and the source of reality. ${ }^{23}$

Scotus asserted that the world was the result of God's will alone, and not the result of any participation in God's nature. ${ }^{24}$ According to John Milbank, this kind of reasoning leads to the conclusion that creation is the result of an arbitrary will. ${ }^{25}$

21. John Milbank, Beyond secular order: the representation of being and the representation of the people (Oxford: Blackwell, 2013), 128-137.

22. "In the thought of the nominalists, following Duns Scotus, the Trinity loses its significance as a prime location for discussing will and understanding in God and the relationship of God to the world. No longer is the world participatorily enfolded within the divine expressive Logos, but instead a bare divine unity starkly confronts the other distinct unities which he has ordained." (Milbank, Theology and social theory:, 15).

23. Conor Cunningham, Genealogy of nihilism: philosophies of nothing and the difference on theology (London: Routledge, 2002), 14-15. "But on the other hand, Trinitarian doctrine suggests that God within himself includes the 'impossible' creative going beyond himself (...) God's creating, since he is omnipotent, can 'only' be in one aspect his going forth within himself and returning to himself in responding to this going forth, while our created derivation from God and returning to God can 'only' be, again because of this omnipotence, entirely one with the event of divine generation and procession." (Milbank, Theology and social theory:, xxvii).

24. "It is possible to dispute the precise tenor of the more extreme voluntarist statements - to the effect, for example, that God might will us to hate himself. This dispute, however, is not all important; what matters is the overwhelming nominalist stress on the gulf between God's potentia ordinata, his declared will, which is factually, precisely known and serves as the basis for legal covenants with humanity, and his potentia absoluta, the infinite power of God which is absolutely unknowable for theology and knowable only formally, for logic." (Milbank, Theology and social theory:, 15).

25. This operation of an arbitrary will is explicitly in Nietzsche, whose thought is influenced by nominalism (Milbank, Theology and social theory:, 286). 
The omnipotence of God is preserved by nominalism, because the world is so completely different (and lower) than God-and not only the world, but also nature, and even rationality. What exists is merely the result of God's Will, and bears no necessary relationship to His nature.

Nominalist authors have had a great philosophical impact on modernity. This impact is what matters in this paper, concerning the presence of nominalism in capitalistic principals, meaning in the contemporary neoliberal politics. In this context, I would like to emphasize three philosophic consequences of nominalism, which are connected with neo-liberal contemporary economics.

The first consequence is autonomy. Although nominalism preserves the omnipotence of God, it abandons the idea of participation. Thus, the world becomes disconnected from God's nature: that means that the worldnature-is autonomous of God's logos. ${ }^{26}$

The second consequence regards the way that reality is made: reality is made by Will, and not by an intrinsic connection to God's nature. So, the will is what determines reality (no matter if it is God's Will or Human Will, because all rational beings particiate in the same Will, as some philosophers of the modernity will affirm). ${ }^{27}$

The third consequence is the subsequent individualism that flows from nominalism. In fact, nominalism affirms that only individual beings exist. Universal beings are only names without ontological consistency: human society, the Church, the Franciscan order-none of these have ontological consistency; only the individuals that compose them do. ${ }^{28}$ Because of this, the point of departure for any analysis will be the individual agent. That is what we see in neo-liberalism in general, and more specifically in the doctrine of the social contract. ${ }^{29}$

26. "It also meant that these essences became more individual, as each distinct essence had its own distinct existence; this autonomy will be radicalised by Ockham." (Cunningham, Genealogy of nihilism:, 14).

27. Frederick Copleston, A history of philosophy, vol. 3: Late medieval and renaissance philosophy (New York: Doubleday, 1993), 94. "one single Will," as we detect in philosophers such a Schopenhauer (Copleston, A history of philosophy, 272). "Yet the obvious implication of 'many truths,' or rather 'many incommensurable truths,' is that every truth is arbitrary, every truth is the will-to-power." (Milbank, Theology and social theory:, 261).

28. Copleston, A history of philosophy, 56.

29. Because it is rooted in an individualistic account of the will, oblivious to questions of its providential purpose in the hands of God, it has difficulty in understanding any 'collective making,' or genuinely social process. To keep notions of the State free from any suggestions of a collective essence or generally recognized telos, it must be constructed on the individualist model of dominium. It is in this inescapable imperative of nominalism-voluntarism that one discovers the kinship at 


\section{The Logic of Capitalism}

In order to demonstrate that neo-liberal contemporary economic principles are not neutral, we must show how the intrinsic logic of nominalism is present in the doctrine of radical free market economics.

Neo-liberal economics is based on an anthropology in which the human person is considered to be a totally autonomous subject. Autonomy is a key category for capitalist ideology on two different levels: (i) on a macro level, the market is considered as an entity that functions (well) without an exterior intervention. In fact, putting restrictions on the "natural" (viz. "autonomous") operation of the market is seen as an abuse and a mistake in that it fails to respect the autonomy of the market; (ii) on a micro level, inside the market, each human individual is seen as an autonomous economic agent, and it is the interaction of the choices of all economics agents that establishes the "equilibrium of the market."30

This brings us to the third consequence of nominalism mentioned above: the tendency towards individualism. Although the doctrine of the free market assumes a socialization of human persons, this socialization is based on individualistic interests. The relations between different agents in the market are made according to the individual will of each agent in order to achieve their particular goals. ${ }^{31}$

When someone buys and sells a house, for instance, each individual in the process attempts to satisfy an individual interest, rather than the interests of all. Even if the orthodox neo-liberals assume that economic agents, in pursuing their own interests, will (in principle) arise to the social optimum, the individualistic tendency is present in the principle assumed. ${ }^{32}$ In other words, free market economics see human selfishness as a good thing which makes the entire system work.

There is an obvious connection between this tendency and the nominalist presumption according to which reality is fundamentally created by Will. As a consequence of this, in the doctrine of the free market, reality is not seen as a

root of modern absolutism with modern liberalism." (Milbank, Theology and social theory:, 14).

30. Assmann and Hinkelammert, L'idolâtrie de marché: critique théologique, 146-147.

31. Milbank, Being reconciled: ontology and pardon, 165-166. "Moreover, if only individuals are real, then political power must derive from the individual will." (Milbank, Beyond secular order:, 163).

32. This is related to what Assmann refers to as 'economic rationality': it is a kind of rationality that establishes laws in human relationships at the same level as Newton's laws of physics; this kind of law presumed that humans necessarily act from an inner egoism in pursuing their own individual interests (Assmann and Hinkelammert, L'idolâtrie de marché: critique théologique, 182-183). 
given-i.e. it is not something discovered, but something made. In other words, reality is a social/human construction. ${ }^{33}$ It does not bear any necessary resemblance to God's nature, or to any exterior entity. The reality of a free market is no different: the social reality in which each human being has some goods and properties to administer is also as it were a social/human construction.

According to capitalism, this constructed reality is produced by the human desires of production and consumption that are intrinsically assumed in the so-called "rules of the market." 34 When we say that the price will grow if the demands grows, and vice versa, we are saying that the reality of the market is determined by the interaction of the will of each economic agent.

This kind of constructivism is present in the main criterion of profit. Profit has become the main principle according to which people operate inside a free market. ${ }^{35}$ This principle assumes that it is possible to create reality in such a market: create products and consume them; create money, riches and wealth.

There is also implicitly a kind of anthropology, according to which human individuals are endowed with the power to achieve, and impose, their own desires. In this sense, Milbank sees in the forces of the free market the presence of Nietzsche-a nominalist Nietzsche, that is-and specifically his principle of the Will-to-power. ${ }^{36}$

I will not discuss the intrinsic violence between human beings that is assumed by the doctrine of the free market. Here it is important simply to note the inner utilitarism of economic neo-liberalism. In fact, conceiving reality as something constructed by human desire and measured by profitability implies a moral criterion according to which human actions and social politics can be evaluated: namely, the criterion of efficacy, as measured by economical profit. ${ }^{37}$

33. Milbank, Beyond secular order:, 104, 128-137.

34. Milbank, Beyond secular order:, 173-175.

35. Franz J. Hinkelammert, "La signification des critères de la décision économique (The significance of the criteria of economic decision)," in L'idolâtrie de marché (The idolatry of the market), Hugo Assmann and Franz J. Hinkelammert (Paris: Cerf, 1993), 297-299.

36. Milbank, Theology and social theory:, 260-261.

37. "Le lucre, ce mot qui, sur les lèvres des moralistes, pourrait avoir des résonances accusatrices, quand il s'agit de l'"instinct de lucre," est pour les économistes un concept parfaitement propre, lié au règne de la libre créativité. Il n'y a désormais plus d'obstacle qui empêche de voir par où passe le meilleur chemin vers le bien de tous." (Assmann and Hinkelammert, L'idolâtrie de marché: critique théologique, 113). 


\section{Contemporary Capitalism Is a Coherentist Philosophy}

All the things that have been said until now were already affirmed by members of the Radical Orthodoxy movement as well as by Liberation theologians. Now, in this present section of my paper, I would like to make a small contribution to the debate. It concerns to the relationship between the doctrine of free market and realism: namely, that a problem with radical neoliberalism is the lack of realism in such a system.

While I agree with Liberal Theologians who criticize neo-liberalism for accepting the inevitability of things like austerity or unemployment, ${ }^{38} \mathrm{I}$ also insist that the current problems that have resulted from the subprime crisis are actually due to a lack of realism in neo-liberalism.

It seems to me that a radical free market lacks realism, because it accepts practices that are not rooted in reality. I mean, its practices need not correspond to any kind of exterior reality.

This is what I want to show in the present section of the paper: a free deregulated market allowed financial practices that were only intelligible according to a non-foundationalist, coherentist philosophy.

In order to understand this point, we must also consider how the criterion of profit works in a free and deregulated market: the market's efficacy is measured by the profitability of its transactions. However, if these internal transactions have no limitations imposed by an outside institution, it means that the process of making profit is being of in terms of its internal coherence, without any reference to external reality. I will illustrate this point by considering the 2007 subprime crisis.

\section{Distinction Between a Foundationalist-Realist Philosophy and a Coherentist Philosophy}

Before I start explaining how the subprime crisis unfolded, it is important to state briefly the difference between a foundationalist philosophy and a coherentist philosophy. Of course, there are many kinds of foundationalist and coherentist philosophies, and there are also authors who consider coherentism to be a kind of foundationalism. However, I will focus on a factor

38. "(...) l'usurpation d'une prétendue rationalité économique par le paradigme du marché n'a été possible parce qu'on est parvenu à imposer, au nom d'une certaine 'rationalité économique,' une complète reformulation du 'sens possible' de la vie humaine dans les sociétés complexes (...) l'économie de marché cherche à invalider (...) toute rediscussion d'objectifs désirables qui ne seraient pas en accord avec ce qui a déjà été défini comme l'unique possible." (Assmann and Hinkelammert, L'idolâtrie de marché: critique théologique, 186). 
that clearly differentiates the two approaches: whether taking external reality into account is needed to justify our knowledge.

To that end, I want to highlight the difference between the two philosophical approaches which concern the correspondence of a system to a substantial reality outside that system. We could say that, according to some foundationalist philosophy, knowledge is achieved on the condition that the "true prepositions" understood by the human intellect correspond to an ontic (material) reality that exists independently of the human subject (even if that reality is perceived by humans via empirical experience). This perception is the basis of knowledge. ${ }^{39}$

39. Of course, I am not saying that, according to foundationalsim, absolutely everything must have some kind of external existence. For example, according to foundationalists, mathematical knowledge is justified without a connection to external reality:

"Foundationalism is a view concerning the structure of the system of justified belief possessed by a given individual. Such a system is divided into "foundation" and "superstructure," so related that beliefs in the latter depend on the former for their justification but not vice versa. However, the view is sometimes stated in terms of the structure of knowledge rather than of justified belief. If knowledge is true justified belief (plus, perhaps, some further condition), one may think of knowledge as exhibiting a foundationalist structure by virtue of the justified belief it involves. In any event, I will construe the doctrine as concerned primarily with justified belief, though I will feel free to speak of knowledge instead from time to time.

The first step towards a more explicit statement of the position is to distinguish between mediate (indirect) and immediate (direct) justification of belief. To say that a belief is mediately justified is to say that it is justified by some appropriate relation to other justified beliefs, e.g., by being inferred from other justified beliefs that provide adequate support for it, or, alternatively, by being based on adequate reasons. Thus if my reason for supposing that you are depressed is that you look listless, speak in an unaccustomedly flat tone of voice, exhibit no interest in things you are usually interested in, etc., then my belief that you are depressed is justified, if at all, by being adequately supported by my justified belief that you look listless, speak in a flat tone of voice .... .

A belief is immediately justified, on the other hand, if its justification is of some other sort, e.g. if it is justified by being based on experience or if it is "self-justified." Thus my belief that you look listless may not be based on anything else I am justified in believing but just on the way you look at me. And my belief that $2+3=5$ may be justified not because I infer it from something else I justifiably believe, but simply because it seems obviously true to me" (William P. Alston, "Foundationalism," in $A$ companion to epistemology, ed. Jonathan Dancy, Ernest Sosa, and Matthias Steup (Oxford: Blackwell, 2010), 382).

"Foundationalists believe that some beliefs are non-inferentially justified, or "foundational," and that all other justified beliefs depend for their justification on these foundational beliefs (...) Some also accept perceptual beliefs, such as the belief that there is a red object in front of one (when one sees such an object), as 
In this approach, a kind of realism is presumed: namely, it is assumed that there is some reality independent of the human subject. This means that reality is not a construction, but rather the basis from which one must depart to build the edifice of knowledge.

Contrary to this approach, coherentism rejects the ontological foundation of knowledge. In order to justify a proposition - meaning, to assure its intelligibility -, it is enough to guarantee that the preposition is inside a coherent logical system. ${ }^{40}$ In other words, coherentism takes validity - that is, internal logical coherence - as the unique criterion of truth.

This approach rejects ontology and the realism behind it. "Truth" is something that the human intellect constructs inside a coherent system: it is not necessary to ensure some kind of correspondence to an exterior reality via empirical experience.

As I showed before, this rejection of ontology is connected with nominalism. Specifically, by rejecting ontology, the idea of participation (i.e. that a system must be rooted in an external reality) is also abandoned. Nominalist philosophy played a role in contemporary capitalism, not only in the matter of individual will, but also by being focused exclusively on the logical coherence of its system, rather than on any kind of foundation in reality.

\section{An Exclusively Coherentist Philosophy behind the Subprime Crises}

I will now try to show how the massive practice of subprime credits, which brought about a global financial crisis, was only possible within this coherentist perspective of validity. It is only from this coherentist perspective that the granting of credit based only on the speculative increase of house prices could have been justified - and it was precisely this practice that triggered the present global financial crisis. Outside a coherentist philosophy this practice would not have been intelligible: its assumption that projected increases in the market value of houses would be realized had no foundation in reality.

foundational." (Michal Huemer, "Foundations and coherence," in A companion to epistemology, ed. Jonathan Dancy, Ernest Sosa, and Matthias Steup (Oxford: Blackwell, 2010), 25).

40. "The coherence theory of justification locates the source of all justification for belief in the relation of coherence. Typically, a system of beliefs is said to cohere well when it is consistent, many of the beliefs in the system are mutually supporting (that is, entail each other or render each other probable), and the system contains few or no anomalies (claims that have no explanation within the system). While foundationalists may grant that coherence plays a role in enhancing the justification of some beliefs, coherentists hold the stronger thesis that coherence can by itself provide justification for belief" (Huemer, "Foundations and coherence," 22-23). 
The 2007 subprime crisis began with a massive campaign to provide loans for buying houses in the USA at the beginning of the new millennium. This generated an increased demand for houses, which naturally increased housing prices. However, credit was often given to people without taking into account whether they had the means to repay the debt. In fact, after issuing loans, lenders issued even more loans to help pay for the original loans. These new loans were issued on the assumption that housing prices would continue to increase, and the collateral was the projected increase in the value of the homes. ${ }^{41}$

It seems clear, especially in retrospect, that the process of offering people credit was not grounded in reality. For it did not take into account whether the debtor could pay back the loans; nor whether the projected increase in housing value would actually be realized. It was a system that had internally valid logic but also a system which was not rooted in reality.

The problem became even worse with the creation of financial products such as CDO [Collateralized Debt Obligation] and later CDS [Credit Default Swap]. At the beginning of 2008, the world financial market lost around 25 trillion US dollars (which is twice the French GDP), due to these poorly conceived and totally unregulated financial products. ${ }^{42}$

We are talking about products that are obligations which have a debt as a guarantee. Thus, instead of having collateral that is a substantial reality (or in philosophical terms, an "ontic reality"), the guarantee was only a debt, which some debtor was supposed to pay according to the projected increase in housing values predicted by the internal logic of this coherentist system.

In the deregulated market, these financial products were evaluated according to the level of risk associated with the debts in the CDOs. However, the process of measuring the risk was made without any connection to the reality of the concrete debtors. Financial institutions treated these products as autonomous of the reality to which they ought to have been connected (by "nature").

So, the debts and combinations of debts became a common product to sell and to buy in the financial market. The lack of realism can be seen in two ways.

First, the speculative price projections of the houses permitted loans to be granted to debtors who lacked the means to repay such loans. Thus, the decision to grant credit was not rooted in reality (viz. the real economic means of the debtor), but in a speculative increase of the market price.

Second, the CDOs became disconnected from the real debt that was supposed to be the guarantee of the obligation in question. Conceived of as an autonomous product, CDOs operated inside the market as ordinary

41. Gaël Giraud, Illusion financière (Financial illusion) (Ivry-sur-Seine: Les Editions de l'Etelier, 2012), 44.

42. Giraud, Illusion financière, 34. 
commodities like bread or milk. Without going into detail, it should be noted that the market price of CDOs increased, not because the value of the loans increased, but simply because of increased demand that was generated by speculation.

As a consequence of this lack of realism, between 2001 and 2007, the price of the houses increased by more than $100 \%$ compared to the average of the entire preceding century. ${ }^{43}$

\section{Conclusion}

In this paper, I have tried to show how the doctrine of radical free market economics contains presuppositions which are founded in the nominalist theology of the late medieval era.

Nominalism is present in contemporary neo-liberal economic principles in conceiving the human person as a radically autonomous subject with the power to achieve its own interests.

A major danger of economic neo-liberalism is its ability to justify practices that are neither rooted in, nor make sense in light of, objective reality. The subprime crisis of 2007 and its disastrous results, which are still being felt in almost all of Europe, could occur only because such unrealistic practices were possible within the framework of a free deregulated market. As I showed before, the financial product called CDOs, as well as the extending of credit to unqualified borrowers, is only intelligible according to a philosophy that does not insist on a correspondence between the internal logic of a coherent system and an exterior substantial reality.

I am not absolutely rejecting all neo-liberal economics or the free market. I do not agree with the catastrophists who see in the subprime crises the inevitable end of capitalism, or even the definitive proof for Marxism. This is not my position.

However, I think that the subprime crisis showed us how capitalism should be reformulated. ${ }^{44}$ In particular, it showed us that markets must be

43. Giraud, Illusion financière, 8.

44. This kind of reform is similar to the proposal made by the economist Gaël Giroud. More specifically, in his Proposal \#10, he states: " a regulation of the financial market is necessary in order to avoid that the banker system operates only in function of their profits (in the short term), even if such profits will destroy the economy outside the banker system." (Giroud and Renouard, Vingt propositions pour réformer, 177-217).

Also Francis Fukuyama assumes that the lack of regulation in banking was the first cause of the financial crisis (Fukuyama, Political order and political decay:, 4-5). 
regulated. Limits should be imposed on financial practices and products: limits that obligate economic agents to take into account a given reality.

To that end, I spoke distinctly about "free market" and about "free deregulated market." It is only the deregulated free market that brought us into the present economic-financial crises. So, I assume that it is possible to conceive of a "free regulated market," which is regulated according to some reasonable and realistic limits.

The principles of a totally free deregulated market are not laws according to which a human society must be governed, contrary to what some extreme neo-liberals argue. In fact, the principles of an unregulated market are not only unnecessary, they are also unreasonable. It does not make sense to extend credit to unqualified lenders-outside of an exclusively coherentist philosophy, that is. It does not make sense to allow the calculated price of a house to grow to levels which no one could ever afford. It makes no sense to "fix" one doomed financial product with another. Yet this is what happened in the subprime crisis. Furthermore, it seems to me that today the imposition of some kind of realism is also necessary in the context of the ecological crises.

The subprime crisis revealed the danger of a coherentist philosophy. Through this experience, we saw that the logical coherence of a system is not sufficient, and that some kind of correspondence to reality itself is necessary. But the crisis shows not only the need of reform for economic policy: it also implies that philosophers and theologians must recover and reappropriate realism in their respective fields.

\section{Bibliography}

Alston, William P. "Foundationalism." In A companion to epistemology, ed. Jonathan Dancy, Ernest Sosa, \& Matthias Steup. Oxford: Blackwell, 2010.

Assmann, Hugo \& Hinkelammert, Franz J. L'idolâtrie de marché: critique théologique de l'économie de marché (Idolatry market: theological critique of the market economy). Translated by C. Durban, \& L. Durban. Paris: Cerf, 1993.

Benedict, Pope XVI. "Encyclical Letter Caritas in veritate [26 Jun. 2009]." AAS 101 (2009).

Cunningham, Conor. Genealogy of nihilism: philosophies of nothing and the difference on theology. London: Routledge, 2002.

Copleston, Frederick. A history of philosophy, vol. 3: Late medieval and renaissance philosophy. New York: Doubleday, 1993.

de Mori, Geraldo. "Une théologie à l'école des pauvres: les nouvelles 'frontières' de la théologie de la libération (A theology at the school of the poor: the new 'boundaries' of liberation theology)." Revue théologique de Louvain, 46, no. Juillet-Septembre (2015). 
Fukuyama, Francis. The end of History and the last man. New York: Free Press, 1992.

Fukuyama, Francis. Political order and political decay: from the industrial revolution to the globalization of democracy. New York: Farrar Straus and Giroux, 2014.

Francis, Pope. "Apostolic Exhortation Evangelii gaudium [24 Nov. 2013]." 256: AAS 105 (2013).

Giroud, Gaël, \& Renouard, Cécile. Vingt propositions pour réformer le capitalisme (Twenty proposals to reform capitalism). Paris: Flamarion, 2012).

Greenspan, Alan. The age of turbulence: adventures in a new world. New York: Pinguin Press, 2007.

Giraud, Gaël. Illusion financière (Financial illusion). Ivry-sur-Seine: Les Editions de l'Etelier, 2012.

Huemer, Michal. "Foundations and coherence." In A companion to epistemology, ed. Jonathan Dancy, Ernest Sosa, \& Matthias Steup. Oxford: Blackwell, 2010.

Hinkelammert, Franz J. "La signification des critères de la décision économique (The significance of the criteria of economic decision)." In L'idolâtrie de marché (The idolatry of the market), ed. Hugo Assmann and Franz J. Hinkelammert. Paris: Cerf, 1993.

Milbank, John. Theology and social theory: beyond secular reason. Oxford: Blackwell, 2006.

Milbank, John. Being reconciled: ontology and pardon. London: Routledge, 2003.

Milbank, John. Beyond secular order: the representation of being and the representation of the people. Oxford: Blackwell, 2013.

Stiglitz, Joseph. Globalization and its discontents. New York: W.W. Norton \& Company, 2002. 